\title{
Anti-TNF- $\alpha$ therapy for sight threatening uveitis
}

\section{E W Lindstedt, G S Baarsma, R W A M Kuijpers, P M van Hagen}

Aim: To describe the effect of additional treatment with antiTNF- $\alpha$ therapy in a case series of 13 patients with serious sight threatening uveitis.

Methods: 13 patients with serious sight threatening uveitis were included, of whom six had Behçet's disease, five had idiopathic posterior uveitis, one had sarcoidosis, and one birdshot retinochoroiditis. Onset and course of ocular inflammation, inflammatory signs, and visual acuity were assessed. Patients were treated with $200 \mathrm{mg}$ (approximately $3 \mathrm{mg} / \mathrm{kg}$ ) infliximab infusion. Repeat infusions were given based on clinical response.

Results: Infliximab treatment resulted in an effective suppression of ocular inflammation in all patients. In patients with non-Behçet's disease uveitis visual acuity in six out of eight improved or was stable. In patients with Behçet's disease visual acuity in five out of six improved or was stable.

Conclusion: Anti-TNF- $\alpha$ treatment may be of value in the treatment of uveitis, and in patients with Behçet's disease, leading to suppression of ocular inflammation, vasculitis, and improvement of vision in the majority. Based on these results a controlled masked study is warranted.

$\mathrm{T}$ he cytokine tumour necrosis factor alpha (TNF- $\alpha)$ is an important factor in the pathogenesis of uveitis. In animal experiments TNF- $\alpha$ has been detected in an early phase of endotoxin induced uveitis in rats. ${ }^{1}$ Increased levels of inflammatory cytokines such as TNF- $\alpha$ have been implicated in the pathogenesis of experimental autoimmune uveitis (EAU) in rats $^{2}$ and in mice. ${ }^{3}$ This cytokine may induce the expression of chemokines, adhesion molecules, and other cytokines involved in the prolongation of inflammation. Inhibition of TNF- $\alpha$ activity results in suppression of Thl effector mechanism, suppresses activation of infiltrating macrophages, and prevents tissue destruction in EAU. ${ }^{45}$ Greiner et al showed that anti-TNF- $\alpha$ therapy modulates peripheral blood $\mathrm{T}$ cells in patients with posterior segment intraocular inflammation, which contributes to the recovery of visual function. ${ }^{6}$

In patients with uveitis including Behçet's disease, TNF- $\alpha$ levels are raised in serum and in aqueous humour. ${ }^{78}$ Because of its pivotal role in inflammation, blockade of TNF- $\alpha$ activity may be effective in the treatment of uveitis. Anti-TNF- $\alpha$ therapies were originally established in rheumatoid arthritis. ${ }^{9}$ Infliximab (Remicade, Schering-Plough) is a chimeric IgG monoclonal antibody directed against TNF- $\alpha$. It binds with high affinity to the soluble and transmembrane forms of TNF. After intravenous administration the half life of infliximab is about 10 days and its biological effect persists for up to 2 months. ${ }^{10}$ Because of its impressive antiinflammatory effects anti-TNF- $\alpha$ therapy has been successfully used in other inflammatory diseases like Crohn's disease, ${ }^{11}$ sarcoidosis, ${ }^{12}$ ankylosing spondylitis, ${ }^{13}$ and psoriatic arthritis. ${ }^{14} 15$ In recent articles favourable results were reported in the treatment of patients with Behçet's disease ${ }^{16}$ and also endogenous uveitis. ${ }^{17-19}$ However, serious side effects have also been reported, including exacerbation of demyelinating disease, ${ }^{20}$ bilateral anterior optic neuropathy, ${ }^{21}$ tuberculosis, ${ }^{22}$ histoplasmosis, ${ }^{23}$ and even sudden death in patients with cardiac insufficiency. These side effects are rare and have to be compared with those of other immunosuppressive and cytotoxic agents which are used to treat these patients. Till the end of August 2003 about 493000 patients worldwide were treated with anti-TNF- $\alpha$ therapy (data retrieved from Centocor). We report our experience of infliximab treatment in a case series of 13 patients with sight threatening uveitis refractory to conventional immunosuppressive therapy. AntiTNF- $\alpha$ therapy may be included in the treatment of sight threatening uveitis.

\section{METHODS}

We investigated whether additional treatment with antiTNF- $\alpha$ therapy had a beneficial effect in 13 patients with serious sight threatening uveitis. Patients were selected because they deteriorated despite treatment with other immunosuppressive drugs such as corticosteroids, cyclosporine, methotrexate and interferon alfa or had serious side effects on these treatments (table 1). Topical non-steroidal anti-inflammatory drugs and steroids were used in all patients.

\section{Treatment}

Six of the 13 patients with longstanding Behçet's disease, fulfilling the international study group criteria were treated. The patient characteristics are summarised in table 1. All patients with Behçet's disease had a history of recurrent sight threatening episodes of uveitis. Five of these patients had only one functional eye. The other eye had a maximal visual acuity of counting fingers or less because of optic atrophy (one), macular lesions (one), phthisis bulbi (one), enucleation (one), or amblyopia (one). Five patients had idiopathic posterior uveitis (two patients with one functional eye), one patient had sarcoidosis, and one birdshot retinochoroiditis (one functional eye). Before the treatment all patients had a extensive physical examination with special attention to tuberculosis, infections, malignancies, cardiac insufficiency, and signs of lupus erythematosus. Routine laboratory investigations were performed (haematogram, kidney, and liver function tests) at baseline and during follow up.

\section{Treatment protocol}

After verbal informed consent we administered $200 \mathrm{mg}$ of infliximab (approximately $3 \mathrm{mg} / \mathrm{kg}$ ) intravenously in an outpatient setting. A series of $1-12$ infusions were given based on clinical response. In case of relapse of disease antiTNF- $\alpha$ therapy was restarted. This means a restart at different intervals for each patient. Initially infliximab was given as additional treatment. Ophthalmological assessment was performed, including Snellen visual acuity, intraocular

Abbreviations: EAU, experimental autoimmune uveitis; MTX, methotrexate; TNF- $\alpha$, tumour necrosis factor alpha 
Table 1 Patient characteristics and previous treatment

\begin{tabular}{|c|c|c|c|c|c|c|c|}
\hline Patients & Presentation* & $\begin{array}{l}\text { Previous systemic } \\
\text { treatment }\end{array}$ & $\begin{array}{l}\text { Duration of } \\
\text { disease (years) }\end{array}$ & Patient & Presentation* & $\begin{array}{l}\text { Previous systemic } \\
\text { treatment }\end{array}$ & $\begin{array}{l}\text { Duration of } \\
\text { disease (years) }\end{array}$ \\
\hline \multicolumn{8}{|c|}{ Behçet's disease: $n=6$, mean age: 44 , range $32-66$} \\
\hline $\begin{array}{l}\text { Patient } 1 \text {, } \\
\text { M; } 38 \text { years, } \\
\text { Behçet's disease }\end{array}$ & $\begin{array}{l}\mathrm{OA}+\mathrm{GU}, \mathrm{A} \\
\mathrm{TF}, \mathrm{BU}\end{array}$ & $\begin{array}{l}\text { Cyclosporine, } \\
\text { colchicine, } \\
\text { interferon alfa, } \\
\text { prednisone }\end{array}$ & 6 & $\begin{array}{l}\text { Patient } 4, \mathrm{M} \text {; } \\
56 \text { years, Behçet's } \\
\text { disease }\end{array}$ & $\begin{array}{l}\mathrm{OA}+\mathrm{GU}, \mathrm{A} \\
\mathrm{SL}, \mathrm{BU}\end{array}$ & $\begin{array}{l}\text { Cyclosporine, } \\
\text { colchicine, } \\
\text { azathioprine }\end{array}$ & 22 \\
\hline $\begin{array}{l}\text { Patient } 2, \\
\text { M; } 32 \text { years, } \\
\text { Behçet's disease }\end{array}$ & $\begin{array}{l}\mathrm{OA}+\mathrm{GU}, \mathrm{A} \\
\mathrm{SL} ; \mathrm{C}, \mathrm{BU}\end{array}$ & $\begin{array}{l}\text { Azathioprine, } \\
\text { interferon alfa }\end{array}$ & 10 & $\begin{array}{l}\text { Patient } 5, M \text {; } \\
34 \text { years, Behçet's } \\
\text { disease }\end{array}$ & $\begin{array}{l}\mathrm{OA}+\mathrm{GU}, \mathrm{A} \\
\mathrm{BU}\end{array}$ & Interferon alfa & 15 \\
\hline $\begin{array}{l}\text { Patient 3, F; } \\
37 \text { years, } \\
\text { Behçet's disease }\end{array}$ & $\begin{array}{l}\mathrm{OA}+\mathrm{GU}, \mathrm{A} \\
\mathrm{TF}, \mathrm{SL}, \mathrm{BU}\end{array}$ & $\begin{array}{l}\text { Cyclosporine, } \\
\text { colchicine, } \\
\text { interferon alfa }\end{array}$ & 6 & $\begin{array}{l}\text { Patient } 6 \text {, } \\
\text { M; } 66 \text { years } \\
\text { Behçet's disease }\end{array}$ & $\begin{array}{l}\mathrm{OA}+\mathrm{GU} \\
\mathrm{A} \\
\mathrm{BU}\end{array}$ & $\begin{array}{l}\text { Cyclosporine } \\
\text { Interferon alfa } \\
\text { Azathioprine, colchicine, } \\
\text { prednisone }\end{array}$ & 7 \\
\hline $\begin{array}{l}\text { Patient } A \text {, } \\
F ; 31 \text { years, } \\
\text { idiopathic uveitis }\end{array}$ & \multicolumn{2}{|c|}{ Prednisone, MTX } & 5 & $\begin{array}{l}\text { Patient E, F; } 38 \\
\text { years, } \\
\text { idiopathic uveitis }\end{array}$ & \multicolumn{2}{|c|}{ Prednisone, cyclosporine } & 4 \\
\hline $\begin{array}{l}\text { Patient } B \text {, } \\
\text { M; } 29 \text { years, } \\
\text { idiopathic uveitis }\end{array}$ & \multicolumn{2}{|c|}{$\begin{array}{l}\text { Cyclosporine, prednisone, } \\
\text { interferon alfa }\end{array}$} & 7 & $\begin{array}{l}\text { Patient } F, M ; 39 \\
\text { years, sarcoidosis }\end{array}$ & \multicolumn{2}{|c|}{ Prednisone, MTX } & 5 \\
\hline $\begin{array}{l}\text { Patient C, F; } \\
62 \text { years, } \\
\text { idiopathic uveitis }\end{array}$ & \multicolumn{2}{|c|}{ Prednisone, cyclosporine } & 2 & $\begin{array}{l}\text { Patient } \mathbf{G} \text {, } \\
\text { F; } 60 \text { years, } \\
\text { birdshot }\end{array}$ & \multirow{2}{*}{\multicolumn{2}{|c|}{ Cyclosporine, prednisone, MTX }} & 10 \\
\hline $\begin{array}{l}\text { Patient } D \text {, } \\
\text { M; } 20 \text { years, } \\
\text { idiopathic uveitis }\end{array}$ & $\begin{array}{l}\text { Cyclosporine, } \\
\text { Octreotide LAR, }\end{array}$ & $\begin{array}{l}\text { Cellcept, } \\
\text {, prednisone }\end{array}$ & 8 & & & & \\
\hline \multicolumn{8}{|c|}{$\begin{array}{l}\text { *OA, oral aphthous lesions: } 6 / 6 ; \\
\text { V, vasculitis in a skin biopsy: } 0 / 6 ; \\
\text { GU, genital ulcerations: } 6 / 6 \text {; } \\
\text { C, colitis/gastrointestinal vasculitis: } 1 / 6 ; \\
\text { A, arthralgia/arthritis (usually a non-symmetric arthritis): } 6 / 6 \text {; } \\
\text { TF, thrombophlebitis: } 2 / 6 \text {; } \\
\text { SL, skin lesions: } 3 / 6 \text {; } \\
\text { BU, bilateral panuveitis (severe panuveitis): } 6 / 6 \text {. }\end{array}$} \\
\hline
\end{tabular}

pressure, slit lamp biomicroscopy, and indirect ophthalmoscopy of the posterior segment. Examinations were performed on day 0 and during follow up for at least 2 years. Inflammatory activity of the anterior and posterior chamber was scored according to Kimura et al. ${ }^{24}$ Presence of retinal vasculitis (choroidal lesions, retinal lesions, vascular sheathing or macular lesions) was scored as well, either + or - or were described (table 2).

An effective suppression of ocular inflammation-that is, quiescence of inflammation in the anterior chamber and/or diminishing of vitreous cell and/or disappearance of vasculitis, along with an improvement or stabilisation of visual acuity together with a clinical improvement both objectively and subjectively reflects successful treatment. We regarded an improvement in VA of more than two decimal points as clinically significant.

\section{RESULTS}

The effects of therapy were assessed in two ways.

\section{Reduction of inflammation}

As shown in table 2 the initial administration of anti-TNF- $\alpha$ therapy resulted in a suppression of ocular inflammation (that is, quiescence of inflammation in the anterior chamber, diminishing of vitreous cell, or disappearance of vasculitis) and clinical improvement in all patients, especially in patients with Behçet's disease. Patients with uveitis and Behçet's disease responded in less than 7 days to 3 weeks after infusion with infliximab, whereas patients with serious uveitis without Behçet's disease responded variably, between 6 days to 2 months. We observed that remission was accomplished in patients with Behçet's disease after 1-3 infusions. The majority of these patients could be controlled subsequently on conventional immunosuppressive therapy only. Concurrent improvement of longstanding orogenital ulcerations occurred within days after the infusion of infliximab in all patients with Behçet's disease. Furthermore, non-ocular inflammatory symptoms such as synoviitis, thrombophlebitis and gastrointestinal lesions improved dramatically or resolved completely within 1 or 2 weeks after infliximab infusion.

\section{Effect on visual acuity}

Subjectively, the improvement of visual acuity started within a few days. Table 3 shows the visual acuity in all 13 patients after at least 2 years of follow up, the number of anti-TNF- $\alpha$ infusions along with subsequent co-medication. Three out of six patients with Behçet's disease - that is, four eyes, had a significant improvement of visual acuity. As has been described in table 3 most eyes had irreversible ocular damage so stable vision in the remaining eyes may indicate some benefit of treatment. Two out of five patients with idiopathic posterior uveitis-that is, two eyes, had a significant improvement of visual acuity, the other eyes were stable ( six eyes) or worsened (two eyes, one eye lost light perception). The patients with sarcoidosis and birdshot retinochoroiditis were stable.

The treatment was well tolerated by most patients. In two patients, the therapy was discontinued; in one because of a rash and in the other one because of development of relapse of atopic dermatitis. In both, the skin lesions disappeared after discontinuation of anti-TNF- $\alpha$ therapy.

In patients 1 and 2 infliximab treatment was restarted, in patient 1 because of polyarthritis and in patient 2 because of a severe refractory colitis. In the patients with idiopathic posterior uveitis 1-4 infusions were needed to achieve remission. The ocular inflammatory activity in patients A, $\mathrm{C}$, and $\mathrm{E}$ was controlled subsequently with conventional immunosuppression. Patient B had a relapse 2 months after the first three infusions and did not respond well to two more infliximab infusions; he was further treated with steroids to control the uveitis. In patient D treatment was stopped after 
Table 2 Effect on inflammation after the first infusion with infliximab

\begin{tabular}{|c|c|c|c|c|c|c|c|c|c|c|c|c|}
\hline Patient & Eye & $\begin{array}{l}\text { VA } \\
T=0\end{array}$ & $\begin{array}{l}\text { VA } \\
T=0+x\end{array}$ & $\begin{array}{l}\mathrm{AC} \\
\mathrm{T}=0\end{array}$ & $\begin{array}{l}A C \\
T=0+x\end{array}$ & $\begin{array}{l}\mathrm{AH} \\
\mathrm{T}=0\end{array}$ & $\begin{array}{l}\mathrm{AH} \\
\mathrm{T}=0+\mathrm{x}\end{array}$ & $\begin{array}{l}\mathrm{VC} \\
\mathrm{T}=0\end{array}$ & $\begin{array}{l}\text { VC } \\
T=0+x\end{array}$ & $\begin{array}{l}F \\
T=0\end{array}$ & $\begin{array}{l}F \\
T=0+x\end{array}$ & $\begin{array}{l}x \text { (days after } \\
\text { infusion) }\end{array}$ \\
\hline \multirow[t]{2}{*}{1} & RE & $20 / 30$ & $20 / 25$ & 3 & 1 & 2 & 1 & 2 & 1 & 1 & 0 & 7 \\
\hline & LE & LP+ & $\mathrm{CF}$ & 3 & 1 & 2 & 1 & 2 & 1 & 1 & 0 & \\
\hline \multirow[t]{2}{*}{2} & RE & $20 / 50$ & $20 / 30$ & 2 & 1 & 2 & 1 & 1 & 0 & 0 & 0 & 6 \\
\hline & LE & LP+ & $\mathrm{LP}+$ & 2 & 1 & 1 & 1 & 2 & 1 & 1 & 0 & \\
\hline \multirow[t]{2}{*}{3} & RE & $20 / 60$ & $20 / 40$ & 2 & 0 & 2 & 1 & 1 & 0 & 1 & 0 & 14 \\
\hline & LE & 0.6 & $20 / 25$ & 1 & 0 & 1 & 1 & 2 & 0 & 0 & 0 & \\
\hline \multirow[t]{2}{*}{4} & $\mathrm{RE}$ & CF & $\mathrm{CF}$ & 2 & 0 & 2 & 1 & 2 & 1 & 1 & 0 & 21 \\
\hline & LE & $20 / 30$ & $20 / 30$ & 2 & 0 & 1 & 1 & 1 & 0 & 0 & 0 & \\
\hline 5 & $\begin{array}{l}\mathrm{RE} \\
\mathrm{LE}\end{array}$ & $\begin{array}{l}20 / 200 \\
\text { Enucleated }\end{array}$ & $20 / 100$ & 2 & 1 & 2 & 1 & 2 & 1 & 1 & 0 & 9 \\
\hline 6 & $\begin{array}{l}\mathrm{RE} \\
\mathrm{LE}\end{array}$ & $\begin{array}{l}\text { CF } \\
\text { Phthisis bul }\end{array}$ & $20 / 200$ & 2 & 1 & 2 & 1 & 1 & 0 & 1 & 0 & 17 \\
\hline \multirow[t]{2}{*}{ A } & $\mathrm{RE}$ & $20 / 150$ & $20 / 80$ & 3 & 2 & 3 & 2 & 3 & 2 & 1 & 0 & 6 \\
\hline & LE & $20 / 200$ & $20 / 100$ & 2 & 1 & 2 & 2 & 2 & 1 & 1 & 0 & \\
\hline \multirow[t]{2}{*}{ B } & $\mathrm{RE}$ & $20 / 40$ & $20 / 20$ & 2 & 1 & 2 & 1 & 1 & $i$ & 1 & 0 & 21 \\
\hline & LE & $\mathrm{CF}$ & $20 / 150$ & 2 & 1 & 3 & 1 & 1 & 1 & 1 & 0 & \\
\hline \multirow[t]{2}{*}{ C } & $\mathrm{RE}$ & $20 / 50$ & $20 / 40$ & 1 & 0 & 1 & 1 & 1 & $i$ & 1 & 0 & 30 \\
\hline & $\mathrm{LE}$ & $\mathrm{LP}+$ & $\mathrm{LP}+$ & 0 & 0 & 0 & 0 & 1 & 0 & 1 & 0 & \\
\hline \multirow[t]{2}{*}{ D } & $\mathrm{RE}$ & $20 / 400$ & $20 / 200$ & 2 & 0 & 2 & 0 & 1 & 0 & 1 & 0 & 55 \\
\hline & $\mathrm{LE}$ & $20 / 120$ & $20 / 120$ & 2 & 0 & 1 & 0 & 0 & 0 & 1 & 0 & \\
\hline \multirow[t]{2}{*}{$\mathrm{E}$} & $\mathrm{RE}$ & $20 / 200$ & $20 / 200$ & 1 & 1 & 3 & 1 & 1 & 1 & 1 & 0 & 12 \\
\hline & LE & $20 / 200$ & $20 / 200$ & 0 & 1 & 1 & 1 & 1 & 1 & 1 & 0 & \\
\hline \multirow[t]{2}{*}{$\mathrm{F}$} & RE & $20 / 40$ & $20 / 40$ & 3 & 0 & 2 & 1 & 1 & 0 & 0 & 0 & 6 \\
\hline & LE & $20 / 60$ & $20 / 40$ & 2 & 0 & 1 & 0 & 2 & 1 & 1 & 0 & \\
\hline \multirow[t]{2}{*}{$G$} & $\mathrm{RE}$ & $20 / 120$ & $20 / 60$ & 0 & 0 & 0 & 0 & 1 & 1 & 0 & 0 & 70 \\
\hline & LE & CF & $20 / 200$ & 0 & 0 & 0 & 0 & 1 & 1 & 0 & 0 & \\
\hline
\end{tabular}

VA, visual acuity according to Snellen equivalent; $\mathrm{AH}$, aqueous haze; $\mathrm{F}$, fundus (presence of vasculitis: 1; no vaculitis: 0 ); $\mathrm{AC}$, aqueous cell; $\mathrm{T}$, time; $\mathrm{VC}$, vitreous cell; CRVO, central retinal vein occlusion.

$\mathrm{x}$ : number of days after start of the first treatment when re-examination was performed.

two infusions because no effect was observed. This was attributed to the pre-existing destructive retinal fibrosis. Patient $F$ responded very well after the first infusion; unfortunately, he developed a rash after three infusions which forced us to stop the treatment. The ocular inflammation is now under control with conventional immunosuppression. The patient with birdshot retinochoroiditis developed a rash after the first infusion and treatment was

\begin{tabular}{|c|c|c|c|c|c|}
\hline Patient & $\begin{array}{l}\text { Total TNF } \\
\text { infusions }\end{array}$ & VA before start & $\begin{array}{l}\text { VA after at least } \\
2 \text { years follow up }\end{array}$ & Fundus lesions & Medications \\
\hline 1 & 11 & $\begin{array}{l}\text { RE: } 20 / 30 \\
\text { LE: } L P+\end{array}$ & $\begin{array}{l}\text { RE: } 20 / 20 \\
\text { LE: CF }\end{array}$ & Macular hole/fibrosis LE & $\begin{array}{l}\text { Infliximab } 200 \mathrm{mg} \text { iv, } \\
\text { prednisone } 1 \mathrm{mg} / \text { day, } \\
\text { prednisone after } 3 \text { months } \downarrow \text { to } 10 \mathrm{mg} / \text { day }\end{array}$ \\
\hline 2 & 4 & $\begin{array}{l}\text { RE: } 20 / 50 \\
\text { LE: LP+ }\end{array}$ & $\begin{array}{l}\text { RE: } 20 / 30 \\
\text { LE: } L P+\end{array}$ & Ischaemic optic atrophy, RE $>$ LE & $\begin{array}{l}\text { Infliximab } 200 \mathrm{mg} \text { iv, } \\
\text { cyclosporine } 200 \mathrm{mg} / \text { day }\end{array}$ \\
\hline 3 & 7 & $\begin{array}{l}\text { RE: } 20 / 60 \\
\text { LE: } 20 / 30\end{array}$ & $\begin{array}{l}\text { RE: } 20 / 80 \\
\text { LE: } 20 / 40\end{array}$ & Optic atrophy, RE $>$ LE & $\begin{array}{l}\text { Infliximab } 200 \text { mg iv, } \\
\text { MTX } 3 \times / \text { week }\end{array}$ \\
\hline 4 & 1 & $\begin{array}{l}\text { RE: CF } \\
\text { LE: } 20 / 30\end{array}$ & $\begin{array}{l}\text { RE: } 20 / 200 \\
\text { LE: } 20 / 30\end{array}$ & Macular fibrosis LE & Infliximab 200 mg iv \\
\hline 5 & 4 & RE: $20 / 200$ & RE: $20 / 200$ & & $\begin{array}{l}\text { Infliximab } 200 \mathrm{mg} \text { iv, } \\
\text { prednisone } 15 \mathrm{mg} / \text { day, } \\
\text { cyclosporine } 300 \mathrm{mg} / \text { day }\end{array}$ \\
\hline 6 & 2 & RE: CF & RE: CF & CRVO; oedema posterior pole RE & $\begin{array}{l}\text { Infliximab } 200 \mathrm{mg} \text { iv, } \\
\text { prednisone } 20 \mathrm{mg} / \text { day, } \\
\text { MTX } 12.5 \mathrm{mg} / \text { week }\end{array}$ \\
\hline A & 12 & $\begin{array}{l}\text { RE: } 20 / 150 \\
\text { LE: } 20 / 200\end{array}$ & $\begin{array}{l}\text { RE: } 20 / 40 \\
\text { LE: } 20 / 100\end{array}$ & Macular scarring RE+LE & $\begin{array}{l}\text { Infliximab } 200 \mathrm{mg} \text { iv, } \\
\text { prednisone } 10 \mathrm{mg} / \text { day, } \\
\text { ledertrexate } 1 \times / \text { week }\end{array}$ \\
\hline B & 5 & $\begin{array}{l}\text { RE: } 20 / 40 \\
\text { LE: CF }\end{array}$ & $\begin{array}{l}\text { RE: } 20 / 40 \\
\text { LE: CF }\end{array}$ & & $\begin{array}{l}\text { Infliximab } 200 \mathrm{mg} \text { iv, } \\
\text { prednisone } 10 \mathrm{mg} / 48 \text { hours }\end{array}$ \\
\hline C & 5 & $\begin{array}{l}\text { RE: } 20 / 50 \\
\text { LE: LP+ }\end{array}$ & $\begin{array}{l}\text { RE: } 20 / 30 \\
\text { LE: LP- }\end{array}$ & Macular scarring RE & $\begin{array}{l}\text { Infliximab } 200 \mathrm{mg} \text { iv, } \\
\text { prednisone } 10 \mathrm{mg} / \text { day, } \\
\text { cyclosporin } 100 \mathrm{mg} / \text { day }\end{array}$ \\
\hline D & 2 & $\begin{array}{l}\text { RE: } 20 / 400 \\
\text { LE: } 20 / 120\end{array}$ & $\begin{array}{l}\text { RE: CF } \\
\text { LE: } 20 / 120\end{array}$ & Fibrosis; disc swelling RE & $\begin{array}{l}\text { Infliximab } 200 \mathrm{mg} \text { iv, } \\
\text { cyclosporin } 100 \mathrm{mg} / \text { day, } \\
\text { prednisone } 15 \mathrm{mg} / \text { day }\end{array}$ \\
\hline$E$ & 4 & $\begin{array}{l}\text { RE: } 20 / 200 \\
\text { LE: } 20 / 200\end{array}$ & $\begin{array}{l}\text { RE: } 20 / 100 \\
\text { LE: } 20 / 100\end{array}$ & Disc swelling RE+LE & Infliximab $200 \mathrm{mg}$ iv \\
\hline $\mathrm{F}$ & 3 & $\begin{array}{l}\text { RE: } 20 / 40 \\
\text { LE: } 20 / 60\end{array}$ & $\begin{array}{l}\text { RE: } 20 / 40 \\
\text { LE: } 20 / 50\end{array}$ & $\begin{array}{l}\text { Macular oedema LE } \\
\text { STOP: dermatitis }\end{array}$ & $\begin{array}{l}\text { Infliximab } 200 \mathrm{mg} \text { iv, } \\
\text { MTX } 15 \mathrm{mg} / \text { week, }\end{array}$ \\
\hline G & 1 & $\begin{array}{l}\text { RE: } 20 / 120 \\
\text { LE: CF }\end{array}$ & $\begin{array}{l}\text { RE: } 20 / 200 \\
\text { LE: CF }\end{array}$ & STOP: rash & $\begin{array}{l}\text { with cyclosporin/MTX } \\
\text { Stable for } 3 \text { years: VA: RES } 0.4-0.1 \text {, when } \\
\text { progression: infliximab } 200 \mathrm{mg} \text { iv }\end{array}$ \\
\hline
\end{tabular}


stopped. This patient deteriorated and is now stable with a VA of 0.1 right eye and counting fingers left eye.

\section{DISCUSSION}

Anti-TNF- $\alpha$ therapy is promising in the treatment of severe sight threatening uveitis, both in patients with Behçet's disease and in idiopathic endogenous uveitis. Our series is a selection of patients in whom maximum visual recovery is limited as a result of irreversible ocular damage. Despite the poor recovery of visual acuity - that is, $7 / 13$ patients showed any improvement in vision, whereas $4 / 13$ patients gained two or more lines, a good clinical response was observed regarding inflammation in the majority of these patients. Clinical trials are necessary to determine the optimal therapeutic strategy in patients with uveitis with regard to dosage and duration of treatment. In our series we observed only minor side effects in two patients. In this small case series of refractory uveitis patients, we did not observe any signs or symptoms of lupus erythematosus. However, those patients were initially treated with other immunosuppressive drugs which may suppress auto-antibody formation. The treatment of posterior uveitis is based on local or systemic immune suppression and the treatment of secondary macular oedema. In most patients, treatment with steroids and cyclosporine reduces the inflammation sufficiently. In a minority of patients other immunosuppressants, such as cytotoxic agents, are necessary as well. A novel approach is treatment with anti-TNF- $\alpha$ therapy. Behçet's disease is not a chronic, persistent inflammation, but rather a disorder characterised by recurrent attacks of acute inflammation. A rapid therapeutic effect is important in Behçet's disease in order to prevent ocular complications that result in irreversible visual impairment because of inflammation, macular oedema, atrophy, or retinal detachment. Here we show that infliximab administration indeed results in a rapid decrease of the inflammation activity. Anti-TNF- $\alpha$ therapy may be added to the therapeutic regimen in the treatment of patients with sight threatening uveitis including uveitis in Behçet's disease. However, controlled masked studies are warranted to determine the optimal dosage and duration of the treatment. The effect of co-medication interaction must also be investigated in this new therapy for uveitis.

In conclusion, anti-TNF- $\alpha$ therapy is promising in the treatment of sight threatening uveitis.

\section{Authors' affiliations \\ E W Lindstedt, G S Baarsma, R W A M Kuijpers, P M van Hagen, The Eye Hospital Rotterdam, Erasmus University Medical Centre Rotterdam,} Netherlands

Correspondence to: Eric W Lindstedt, The Eye Hospital Rotterdam, Erasmus University Medical Centre Rotterdam, Netherlands; elindstedt@ oogziekenhuis.nl

Accepted for publication 1 October 2004

\section{REFERENCES}

1 De Vos AF, Klaren VN, Kiilstra. Expression of multiple cytokines and IL-1RA in the uvea and retina during endotoxin-induced uveitis in the rat. Invest Ophthalmol Vis Sci 1994;35:3873-83.

2 Okada AA, Sakai J, Usui M, et al. Intraocular cytokine quantification of experimental autoimmune uveoretinitis in rats. Ocul Immunol Inflamm 1998;6: $111-20$.

3 Nakamura S, Yamakawa T, Sugita M, et al. The role of tumor necrosis factoralpha in the induction of experimental uveoretinitis in mice. Invest Ophthalmol Vis Sci 1994;35:3884-9.

4 Dick AD, Duncan L, Hale G, et al. Neutralizing TNF-alpha activity modulates T-cell phenotype function in experimental autoimmune uveoretinitis. J Autoimmun 1998;11:255-64.

5 Robertson M, Liversidge J, Forrester JV, et al. Neutralizing tumor necrosis factor-alpha activity suppresses activation of infiltrating macrophages in experimental autoimmune uveoretinitis. Invest Ophthalmol Vis Sci 2003;44:3034-41.

6 Greiner K, Murphy CC, Willermain F, et al. Anti-TNFalpha therapy modulates the phenotype of peripheral blood CD4+ T cells in patients with posterior segment intraocular inflammation. Invest Ophthalmol Vis Sci 2004;45:170-6.

7 Santos Lacomba M, Marcos Martin C, Gallardo Galera JM, et al. Aqueous humor and serum tumor necrosis factor- $\alpha$ in clinical uveitis. Ophthalmic Res 2001;33:251-5.

8 Turan B, Gallati $\mathrm{H}$, Erdi $\mathrm{H}$, et al. Systemic levels of the $\mathrm{T}$ cell regulatory cytokines IL-10 and IL-12 in Behçet's disease; soluble TNFR-75 as a biological marker of disease activity. J Rheumatol 1997;24:128-32.

9 Maini R, St Clair EW, Breedveld F, et al. Infliximab (chimeric anti-tumour necrosis factor $\alpha$ monoclonal antibodyl versus placebo in rheumatoid arthritis patients receiving concomitant methotrexate: a randomised phase III trial. ATTRACT Study Group. Lancet 1999;354:1932-9.

10 Kavanaugh A, St Clair EW, McCune WJ, et al. Chimeric anti-tumor necrosis factor-alpha monoclonal antibody treatment of patients with rheumatoid arthritis receiving methotrexate therapy. J Rheumatol 2000;27:841-50.

11 Sandborn WJ, Hanauer SB. Antitumor necrosis factor therapy for inflammatory bowel disease: a review of agents, pharmacology, clinical results, and safety. Inflamm Bowel Dis 1999;5:119-33.

12 Serio RN. Infliximab treatment of sarcoidosis. Ann Pharmacother 2003;37:577-81.

13 Braun J, Brandt J, Listing J, et al. Treatment of active ankylosing spondylitis with infliximab: randomised controlled multicentre trial. Lancet 2002;359:1 187-93.

14 Ogilvie AL, Antoni C, Dechant C, et al. Treatment of psoriatic arthritis with antitumour necrosis factor-alpha antibody clears skin lesions of psoriasis resistant to treatment with methotrexate. Br J Dermatol 2001;144:587-9.

15 Wollina U, Konrad $\mathrm{H}$. Treatment of recalcitrant psoriatic arthritis with antitumor necrosis factor-alpha antibody. J Eur Acad Dermatol Venereol 2002; 16:127-9.

16 Sfikakis PP, Theodossiadis PG, Katsiari CG, et al. Effect of infliximab on sightthreatening panuveitis in Behçet's disease. Lancet 2001;358:295-6.

17 El-Shabrawi Y, Hermann J. Anti-tumor necrosis factor-alpha therapy with infliximab as an alternative to corticosteroids in the treatment of human leukocyte antigen B27-associated acute anterior uveitis. Ophthalmology 2002; 109:2342-46.

18 Smith JR, Levinson RD, Holland GN, et al. Differential efficacy of tumor necrosis factor inhibition in the management of inflammatory eye disease and associated rheumatic disease. Arthritis Rheum 2001;45:252-7.

19 Reiff A, Takei S, Sadeghi S, et al. Etanercept therapy in children with treatment-resistant uveitis. Arthritis Rheum 2001;44:1411-15.

20 Sicotte NL, Voskuhl RR. Onset of multiple sclerosis associated with anti-TNF therapy. Neurology 2001;57:1885-8.

21 ten Tusscher MP, Jacobs PJ, Busch MJ, et al. Bilateral anterior toxic optic neuropathy and the use of infliximab. BMJ 2003;326:579.

22 Keane J, Gershon S, Wise RP, et al. Tuberculosis associated with infliximab, a tumour necrosis factor alpha-neutralizing agent. N Eng J Med 2001;345:1098-104.

23 Lee JH, Slifman NR, Gershon SK, et al. Life-threatening histoplasmosis complicating immunotherapy with tumour necrosis factor alpha antagonists infliximab and etanercept. Arthritis Rheum 2002;46:2565-70.

24 Kimura SJ, Thygeson P, Hogan MJ. Signs and symptoms of uveitis. I. Anterior uveitis. Am J Ophthalmol 1959;47:155-70. 